\title{
Classification and investigation of Asian aerosol absorptive properties
}

\author{
T. Logan ${ }^{1}$, B. Xi ${ }^{1}$, X. Dong ${ }^{2,1}$, Z. Li ${ }^{3}$, and M. Cribb ${ }^{3}$ \\ ${ }^{1}$ University of North Dakota, Grand Forks, ND, USA \\ ${ }^{2}$ GCESS, Beijing Normal University, Beijing, China \\ ${ }^{3}$ University of Maryland, College Park, MD, USA
}

Correspondence to: X. Dong (dong@aero.und.edu)

Received: 4 July 2012 - Published in Atmos. Chem. Phys. Discuss.: 1 August 2012

Revised: 28 January 2013 - Accepted: 10 February 2013 - Published: 26 February 2013

\begin{abstract}
Asian aerosols are among the most complex yet widely studied components of the atmosphere not only due to their seasonal variability but also their effects on climate change. Four Aerosol Robotic Network (AERONET) sites have been selected to represent aerosol properties dominated by pollution (Taihu), mixed complex particle types (Xianghe), desert-urban (SACOL), and biomass (Mukdahan) in East Asia during the 2001-2010 period. The volume size distribution, aerosol optical depth ( $\tau$ and $\tau_{\text {abs }}$ ), Ångström exponent ( $\alpha$ and $\alpha_{\text {abs }}$ ), and the single scattering co-albedo ( $\left.\omega_{\text {oabs }}\right)$ parameters over the four selected sites have been used to (a) illustrate seasonal changes in aerosol size and composition and (b) discern the absorptive characteristics of black carbon (BC), organic carbon (OC), mineral dust particles, and mixtures. A strongly absorbing mineral dust influence is seen at the Xianghe, Taihu, and SACOL sites during the spring months (MAM), as given by coarse mode dominance, mean $\alpha_{440-870}<1$, and mean $\alpha_{\mathrm{abs} 440-870}>1.5$. There is a shift towards weakly absorbing pollution (sulfate) and biomass (OC) aerosol dominance in the summer (JJA) and autumn (SON) months, as given by a strong fine mode influence, $\alpha_{440-870}>1$, and $\alpha_{\text {abs } 440-870}<1.5$. A winter season (DJF) shift toward strongly fine mode, absorbing particles (BC and OC) is observed at Xianghe and Taihu $\left(\alpha_{440-870}>1\right.$ and $\alpha_{\mathrm{abs} 440-870}>1.5$ ). At Mukdahan, a strong fine mode influence is evident year round, with weakly and strongly absorbing biomass particles dominant in the autumn and winter months, respectively, while particles exhibit variable absorption during the spring season. A classification method using $\alpha_{440-870}$ and $\omega_{\text {oabs } 440}$ is developed in order to infer the seasonal physico-chemical properties of the aerosol types, such
\end{abstract}

as fine and coarse mode, weak and strong absorption, at the four selected Asian sites.

\section{Introduction}

Aerosols originating from the Asian continent have been studied over recent decades and continue to be of great importance due to their varying nature. Ongoing urbanization and industrialization in Asia have generated a wide variety of pollution type aerosols in the atmosphere and have consequently added more uncertainty when evaluating global climate change (Hansen and Sato, 2001; Bergstrom et al., 2007; Eck et al., 2010). In addition, mineral dust and biomass burning episodes can also contribute to the total aerosol loading in the atmosphere (Li et al., 2007a, b; Dubovik et al., 2002; Gautam et al., 2012). Asian dust episodes are more probable and intense during the spring months (Logan et al., 2010; Li et al., 2007b; Huang et al., 2008a; Yang et al., 2008), while biomass burning events generally occur as a result of deforestation, agricultural activities, and natural wildfires (Reid et al., 1999; Eck et al., 1999; Gautam et al., 2012).

Studies have shown how different aerosol particles can interact during transport (Eck et al., 2005, 2010; Schuster et al., 2005). These particles can combine physically and in some cases chemically with one another, thus altering their scattering and/or absorptive capabilities (Levin et al., 1996; Schuster et al., 2005; McNaughton et al., 2009; Reid et al., 1999; Streets et al., 2007; Clarke et al., 2004). Carbonaceous particles containing black carbon (BC) absorb across much of the solar spectrum (between 0.38 and $1 \mu \mathrm{m}$ ), while those 
containing organic carbon (OC) strongly absorb in the UV and visible wavelengths but have weak absorption in the near IR (infrared) (Schuster et al., 2005; Lack and Cappa, 2010; Eck et al., 2005; Lewis et al., 2008). Mineral dust has similar absorptive properties to $\mathrm{OC}$ but has even weaker absorption in the near IR (Bergstrom et al., 2007). As a result, the influences of aerosols ultimately act as negative radiative forcing agents by reducing the amount of direct downwelling solar radiation to the surface, creating a cooling effect ( $\mathrm{Li}$ et al., 2007a, b; Bergstrom et al., 2007; Ramanathan et al., 2001). In addition, aerosols also indirectly affect climate by altering cloud microphysical properties such as cloud albedo, lifetime and precipitation (Li et al., 2007a, b; IPCC, 2007; Ramanathan et al., 2001).

The varying composition of the particles within aerosol events is often difficult to measure directly but has been shown to have a regional and seasonal dependence in particle size (Gobbi et al., 2007; Russell et al., 2010; Eck et al., 2005; Li et al., 2007b; Schuster et al., 2005; Dubovik et al., 2002). Recent research has emphasized that quantifying aerosol effects on climate change requires much information on not just the measurements of aerosol loading but also on their physico-chemical properties (i.e., physical properties due to their chemical composition) (Russell et al., 2010; Kaufman et al., 2002; Dubovik et al., 2002; Lewis et al., 2008; Clarke et al., 2004). Rather than focusing solely on particle size and concentration as a measure for aerosol climactic effects, the physico-chemical properties can be inferred from their absorptive properties (Russell et al., 2010; Schuster et al., 2005; Dubovik et al., 2002; Bergstrom et al., 2007; Lack and Cappa, 2010; Clarke et al., 2004).

Previous studies have suggested that it is possible to reduce the ambiguities in identifying aerosol composition by using the parameters aerosol optical depth $[\tau(\lambda)]$, aerosol absorption optical depth $\left[\tau_{\mathrm{abs}}(\lambda)\right]$, Ångström exponent $(\alpha)$, and the single scattering albedo $\left[\omega_{0}(\lambda)\right]$ (Russell et al., 2010; Lewis et al., 2008; Bergstrom et al., 2007; Jeong and Li, 2005; Higurashi and Nakajima, 2002). These methods, however, are dependent upon the total volume extinction and absorption ( $\beta_{\text {ext }}$ and $\left.\beta_{\text {abs }}\right)$ of all particles present in an aerosol mixture. This can introduce some uncertainties in identifying the predominant aerosol composition in a mixture because pollution particles can have similar size distributions and $\tau(\lambda)$ values but not necessarily the same internal properties (Schuster et al., 2005; Higurashi and Nakajima, 2002).

Four Asian AERONET sites - Xianghe, Taihu, SACOL, and Mukdahan - have been selected for this study because they represent regions affected primarily by mineral dust, pollution, biomass burning aerosols, and complex mixtures of various particle types (Gautam et al., 2012; Eck et al., 2005; Xin et al., 2007; Bi et al., 2010). For example, Eck et al. (2005) found good agreement between the Beijing and Xianghe AERONET data sets in the 2001 spring season and suggested that Xianghe can be influenced by locally generated pollution, mineral dust from nearby desert regions, and even biomass particles from Russia. Xin et al. (2007) used $\tau_{500}$ and $\alpha_{440-650}$ to discern different aerosol types in several Chinese cities, including Xianghe, Taihu, and Lanzhou; while Bi et al. (2010) used $\tau_{500}, \alpha_{440-870}, \omega_{0}$, and the refractive index to show how the SACOL site was seasonally influenced by contributions from both dust and anthropogenic aerosols. Mukdahan is a poorly characterized region in Thailand with few studies. However, the Gautam et al. (2012) study did show biomass and anthropogenic aerosol influences using AERONET observations.

The current study will use particle volume size distribution, the $\tau_{440}, \tau_{\mathrm{abs} 440}, \alpha, \alpha_{\mathrm{abs}}, \omega_{\mathrm{o}}$, and the single scattering co-albedo $\left(1-\omega_{0}\right.$ or henceforth known as $\left.\omega_{\text {oabs }}\right)$ parameters to (1) report the relative influence and seasonal variation of aerosols at the four Asian AERONET sites, and (2) infer how their composition is a likely combination of multiple constituents (e.g., BC, OC, sulfate, and mineral dust particles). A discussion of the methodology used in the retrieval and usage of AERONET observations is outlined in Sect. 2. A brief discussion on how the overall mean extinctive and absorptive properties can be inferred by wavelength dependences of $\tau, \tau_{\mathrm{abs}}$, and $\omega_{\text {oabs }}$ is detailed in Sect. 3. The seasonal variations of aerosol size and absorptive properties are presented and discussed in Sect. 4. The feasibility of using the $\alpha$ and $\omega_{\text {oabs }}$ parameters in a classification method is discussed in Sect. 4.3. This method will demonstrate how the absorptive nature of the aerosols varies as a function of season and region. Finally, Sect. 5 includes a brief summary and conclusion of our results.

\section{Data and methodology}

\subsection{AERONET}

The AErosol RObotic NETwork (AERONET) consists of CIMEL sun/sky radiometers placed in a world-wide framework of observation stations (Holben et al., 1998). The instruments are capable of retrieving aerosol optical products at discrete wavelengths ranging from 340 to $1020 \mathrm{~nm}$ (Schuster et al., 2006; Eck et al., 2005). This study uses level 2.0 (cloud screened, quality assured) products to ensure data quality and accuracy (Holben et al., 2006). The aerosol products were generated using the inversion techniques developed by Dubovik and King (2000) and Dubovik et al. (2000), and quality assurance using Holben et al. (2006). Daily averaged data collected from the four AERONET sites span the following years: 2001-2010 (Xianghe), 2005-2010 (Taihu), 2006-2011 (SACOL), and 2003-2009 (Mukdahan).

The AERONET products analyzed in this study include aerosol optical depth $[\tau(\lambda)]$ ( $\lambda$ between 440 and $1020 \mathrm{~nm}$ ), single scattering albedo $\left[\omega_{0}(\lambda)\right]$, particle effective radius $\left(r_{\mathrm{eff}}\right)$, and the volume particle size distribution. We use $\tau(\lambda)$ and $\omega_{0}(\lambda)$ to calculate the $\tau_{\mathrm{abs} 440}, \alpha_{440-870}, \alpha_{\mathrm{abs} 440-870}$, and $\omega_{\text {oabs }}$ parameters. The uncertainties of $\tau(\lambda)$ and $\omega_{0}$ are 
Table 1. Summary of statistical data from the four AERONET sites. Yearly means of $r_{\text {eff }}$ are calculated from the seasonal mean values due to an uneven distribution of seasonal data.

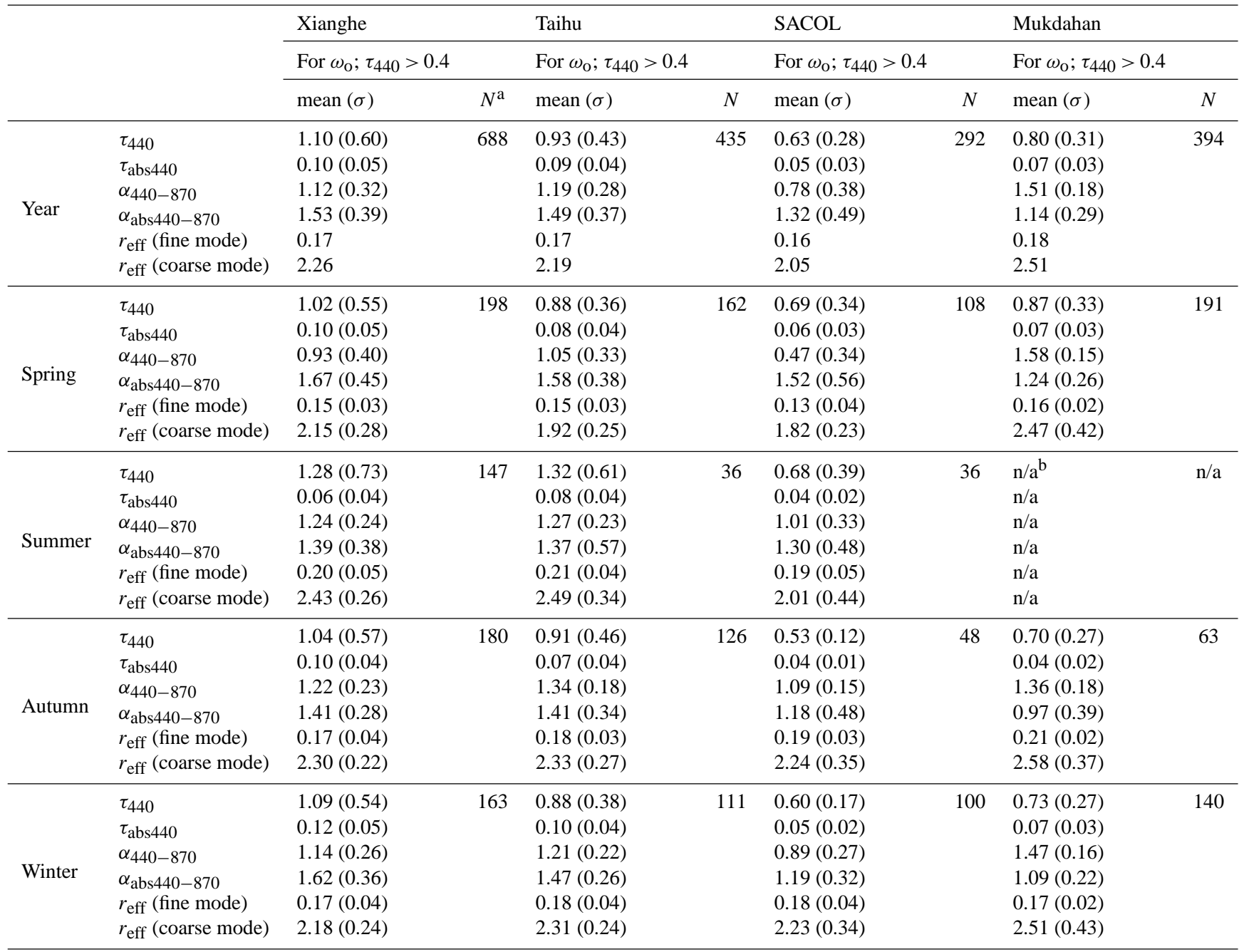

${ }^{a}$ Number of AERONET observations, ${ }^{b}$ Only one data point for this season.

approximately \pm 0.01 and \pm 0.03 , respectively, for $\tau_{440}>0.4$ (Holben et al., 1998; Eck et al., 1999; Dubovik et al., 2002). Though this threshold may bias our results, our conclusions are not greatly affected by using $\tau_{440}>0.4$. It should be noted that the AERONET observations are usually discontinuous and may only contain one almucantar in a day, thus the number of samples over the four selected sites is included in Table 1.

\section{AERONET sites}

The locations of the four selected AERONET sites, Xianghe $\left(39.75^{\circ} \mathrm{N}, 116.96^{\circ} \mathrm{E}\right)$, Taihu $\left(31.4^{\circ} \mathrm{N}, 120.21^{\circ} \mathrm{E}\right)$ and SACOL $\left(35.95^{\circ} \mathrm{N}, 104.14^{\circ} \mathrm{E}\right)$ in China, and Mukdahan in Thailand $\left(16.61^{\circ} \mathrm{N}, 104.68^{\circ} \mathrm{E}\right)$, are shown in Fig. 1. Xianghe is located in a mixture region that is influenced by pollution, biomass burning and mineral dust particles (Eck et al., 2005,
2010; Logan et al., 2010). The other three sites represent an urban region (Taihu), a desert-urban region (SACOL) and a biomass dominant region (Mukdahan). Taihu is located in a region heavily influenced by airflow from large urban centers (e.g., Shanghai and Hangzhou) and industry in each cardinal direction, and to a lesser extent the influences of the Gobi and Taklamakan Deserts (Xin et al., 2007). SACOL, the SemiArid Climate and Environment Observatory of Lanzhou University, is situated in central China (Gansu province) within the reaches of the Loess Plateau (downwind of Gobi and Taklamakan Deserts) (Xin et al., 2007; Huang et al., 2008b). The site is just southeast of Lanzhou City, a large metropolitan and industrial center $(\sim 3.5$ million inhabitants). Mukdahan is located in extreme eastern Thailand near the Laotian border where crop and vegetation burning is prominent during the dry season (Gautam et al., 2012). 


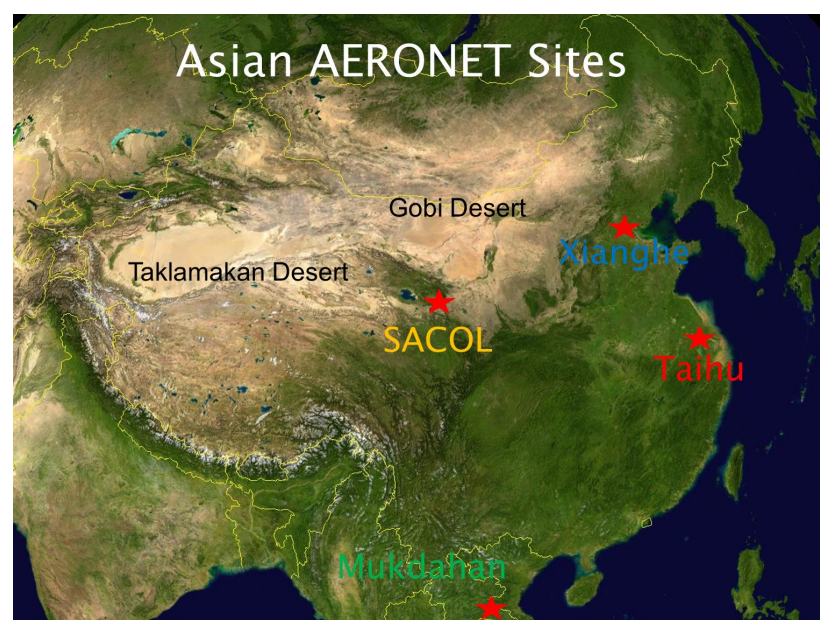

Fig. 1. Four selected AERONET observational sites used in this study. Note the proximities of Xianghe, SACOL and Taihu to the Gobi and Taklamakan deserts, while Mukdahan is not near any desert or large urban areas.

\subsection{Aerosol classification methodology}

\subsubsection{Aerosol optical depth, Ångström exponent, and spectral variation}

Aerosol optical depth is the amount of light extinction integrated vertically through a column of atmosphere and is also the sum of the scattering and absorption optical depths of the medium (Eck et al., 1999). It can be retrieved from many observational platforms (e.g., ground based, sub-orbital in situ, and space based) and is used as a primary parameter in quantifying the magnitude of aerosol loading in an atmospheric column (Holben et al., 1998; Eck et al., 1999; Li et al., 2007a, b). The Ångström exponent, $\alpha$, is a good indicator of the size of particles and is given by the following equation:

$\alpha=-\frac{\ln \left[\frac{\tau\left(\lambda_{1}\right)}{\tau\left(\lambda_{2}\right)}\right]}{\ln \left[\frac{\left(\lambda_{1}\right)}{\left(\lambda_{2}\right)}\right]}$,

where the $\log$-slope relationship between $\tau$ and $\lambda$ is synonymous with wavelength dependence due to particle size (Eck et al., 1999; Schuster et al., 2006). The wavelength range used in this study is 440 to $870 \mathrm{~nm}$. The $\alpha_{440-870}$ parameter can range from negative values to greater than 1 (Higurashi and Nakajima, 2002; Gobbi et al., 2007; Eck et al., 1999). Though there are numerous studies that use an array of $\alpha_{440-870}$ values to partition aerosols according to size, this study adopts $\alpha_{440-870}<0.75$ to denote coarse mode particles while $\alpha_{440-870}>0.75$ denotes fine mode particles (Eck et al., 2005).

\subsubsection{Volume size distribution, $\omega_{0}, \tau_{\mathrm{abs}}, \omega_{\mathrm{oabs}}$, and $\alpha_{\mathrm{abs}}$}

We use the particle volume size distribution as a general fingerprint for each region (Dubovik et al., 2002; Eck et al., 2005). Bimodal distributions tend to suggest more than one type of aerosol, and the total volume of the coarse and fine modes will indicate the size dominance in that region (Dubovik et al., 2002). However, this does not give information on aerosol composition since pollution and biomass particles can yield similar size distributions.

The single scattering co-albedo ( $\omega_{\text {oabs}}$ ) (ratio of absorption to extinction aerosol optical depths) explains the loss of photons to absorption, which is useful in identifying particle composition, especially carbonaceous particles (Corrigan et al., 2006). It is used along with $\tau$ to calculate $\alpha_{\text {abs }}$ where this parameter can (a) reduce ambiguities in aerosol composition and (b) reveal a correlation between $\alpha_{\text {abs }}$ and aerosol composition (e.g., Russell et al., 2010; Bergstrom et al., 2002, 2007; Eck et al., 2010; Giles et al., 2011). The $\alpha_{\text {abs }}$ parameter is calculated starting with the absorption aerosol optical depth, $\tau_{\mathrm{abs}}(\lambda)$, given by

$\tau_{\mathrm{abs}}(\lambda)=\left(1-\omega_{\mathrm{o}}(\lambda)\right) \cdot \tau(\lambda)$,

where we use $\lambda$ at 440 and $870 \mathrm{~nm}$. The same equation for $\alpha$ (Eq. 1 and same $\lambda$ range) is used to calculate $\alpha_{\text {abs }}$ :

$\alpha_{\mathrm{abs}}=-\frac{\ln \left[\frac{\tau_{\mathrm{abs}}\left(\lambda_{1}\right)}{\tau_{\mathrm{abs}}\left(\lambda_{2}\right)}\right]}{\ln \left[\frac{\left(\lambda_{1}\right)}{\left(\lambda_{2}\right)}\right]}$,

and similarly, $\alpha_{\mathrm{abs}}$ is the log-slope relationship between $\tau_{\mathrm{abs}}$ and $\lambda$, which relates absorption wavelength dependence with particle composition (Bergstrom et al., 2004, 2007; Russell et al., 2010).

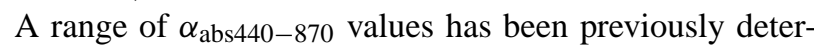
mined which corresponds to various aerosol types. For example, black carbon (submicron) particles have $\alpha_{\mathrm{abs} 440-870}$ close to unity (Russell et al., 2010; Bergstrom et al., 2007; Gyawali et al., 2009). Urban pollution and biomass particles typically have $\alpha_{\mathrm{abs} 440-870}$ ranging from $\sim 1$ to 2 or greater, depending on the relative amounts of $\mathrm{BC}, \mathrm{OC}$, and sulfate, while mineral dust particles can be 1.5 or higher depending on chemical composition (Giles et al., 2011; Lack and Cappa, 2010; Russell et al., 2010; Xin et al., 2007; Schuster et al., 2005). Although $\alpha_{\text {abs } 440-870}$ can be used to discern various aerosol types, it has a limitation, in particular when different aerosols having similar wavelength dependence are mixed with one another (Lack and Cappa, 2010; Bergstrom et al., 2007; Higurashi and Nakajima, 2002).

\section{The wavelength dependences of $\tau, \tau_{\mathrm{abs}}$, and $\omega_{\mathrm{oabs}}$}

The Chung et al. (2012) study used wavelength dependence of AERONET retrieved $\tau$ and $\tau_{\text {abs }}$ to partition aerosols according to type (e.g. mineral dust, $\mathrm{BC}$ and $\mathrm{OC}$ ). They paid 

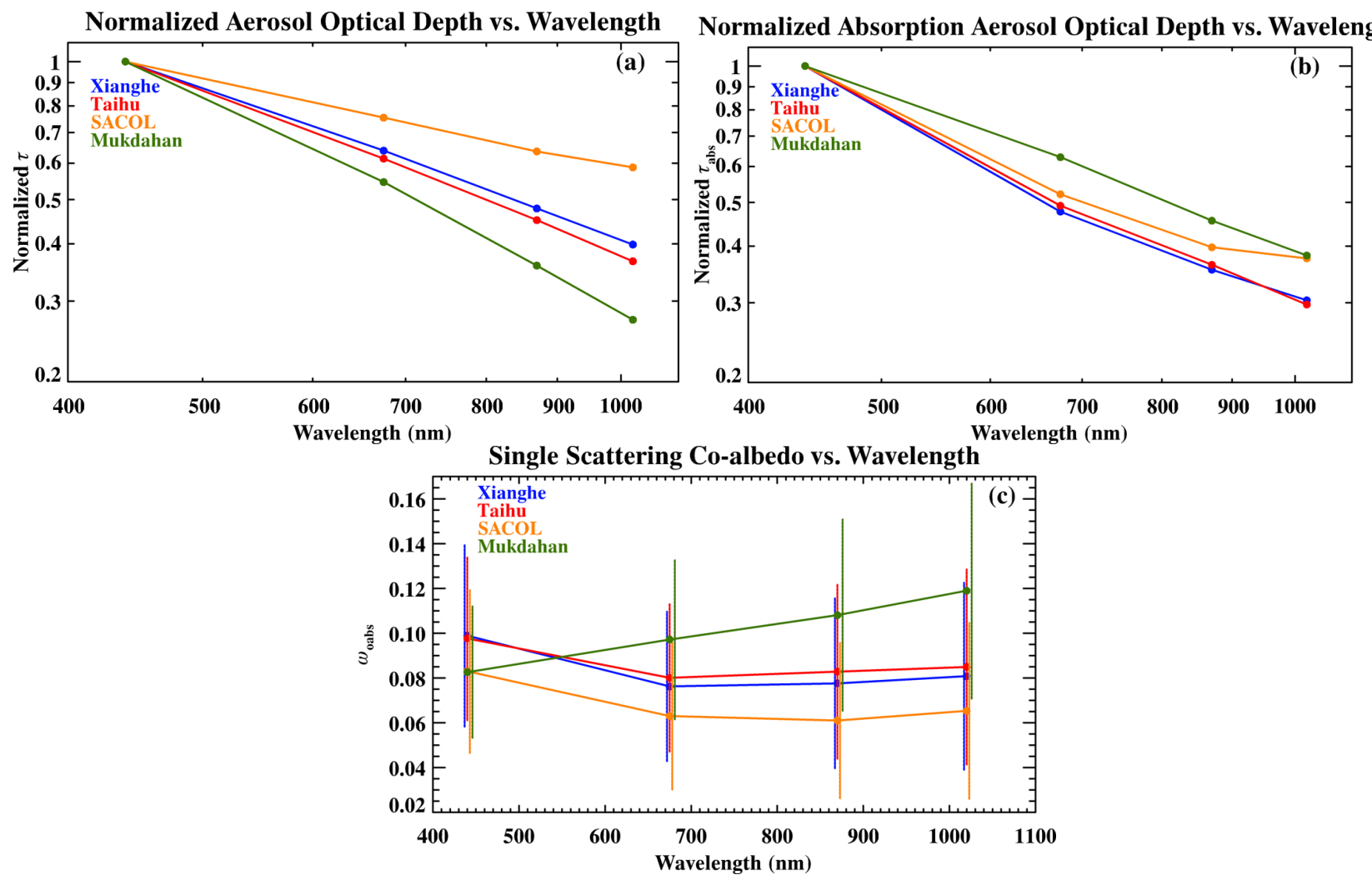

Fig. 2. (a) Log-log relationship of the mean extinction aerosol optical depth wavelength dependence for all aerosol cases at each site: 20012010 (Xianghe), 2005-2010 (Taihu), 2006-2011 (SACOL), and 2003-2009 (Mukdahan). The $\tau$ values are given as ratios to $\tau_{440 \mathrm{~nm}}$ after Chung et al. (2012) to show the degree of wavelength dependence from the visible to near IR. (b) Same as (a) but for absorption aerosol optical depth. (c) Wavelength dependence of the single scattering co-albedo $\left(\omega_{\text {oabs }}\right)$ with error bars denoting $1 \sigma$.

special attention to the role of $\mathrm{OC}$ regarding the absorptive properties of carbonaceous aerosols and their inherent radiative forcing, which is typically ignored in many climate models (Chung et al., 2012). In Fig. 2a and b, the $\tau$ and $\tau_{\text {abs }}$ values at all wavelengths are normalized to their $440 \mathrm{~nm}$ values in order to illustrate the relative mean extinctive and absorptive properties of all aerosol retrievals at each site. As illustrated in Fig. 2a, SACOL has the weakest wavelength dependence of all four sites, indicating coarse mode particles (Logan et al., 2010; Chung et al., 2012). Mukdahan has the strongest wavelength dependence, which suggests fine mode particle dominance (Logan et al., 2010; Chung et al., 2012). Xianghe and Taihu have a wavelength dependence between the other two sites due influences from both coarse and fine mode particles, with Xianghe having more of a coarse mode influence (closer proximity to desert regions) while Taihu has a more fine mode influence (more sources of urban/industrial aerosols) (Eck et al., 2005; Xin et al., 2007; Logan et al., 2010).

In terms of absorption (Fig. 2b), Mukdahan has a near linear $\tau_{\text {abs }}$ wavelength dependence, which is likely indicative of biomass burning aerosols generated from different combustion phases with $\mathrm{BC}$ dominating the overall absorption (Reid et al., 1999; Andreae and Gelencsér, 2006; Lack and Cappa, 2010). Xianghe and Taihu have a stronger $\tau_{\text {abs }}$ wavelength dependence in the visible that weakens in the near IR, suggesting OC dominant carbonaceous aerosols. SACOL has a similar wavelength dependence in the visible that becomes negligible in the near IR, primarily indicating mineral dust particles with varying amounts of iron oxides (Koven and Fung, 2006; Chung et al., 2012).

Figure $2 \mathrm{c}$ offers an alternative perspective of the aerosol absorptive properties at the four sites. We propose that the wavelength dependence of the single scattering co-albedo $\left(\omega_{\text {oabs }}\right)$ can be used to better separate the different aerosol types by comparing the relative amount of absorption in the visible $(440-675 \mathrm{~nm})$ to the near IR $(>675 \mathrm{~nm})$. The $\omega_{\text {oabs }}$ parameter demonstrates the absorptive nature due to the internal composition of the particles rather than particle loading since it is basically a ratio of $\tau_{\text {abs }}$ to $\tau$. At Mukdahan, the carbonaceous biomass particles tend to have a nearly linear increase in absorption with wavelength, which is indicative of more influence of $\mathrm{BC}$ though there are likely $\mathrm{OC}$ influences as well (Bergstrom et al., 2007; Gautam et al., 2012). In contrast, the SACOL site has strong absorption in the visible but becomes weak in the near IR because dust particles 
are typically in the coarse mode and tend to scatter in the near IR region (Bergstrom et al., 2007). The Xianghe and Taihu sites nearly mirror one another with strong absorption in the visible but an increase in absorption with wavelength in the near IR, again indicating the influences of absorbing carbonaceous particles, similar to Mukdahan.

The absorptive characteristics of the aerosols at each site become less ambiguous with $\omega_{\text {oabs }}$ as opposed to $\tau_{\text {abs }}$ in that more information about aerosols can be inferred by the $\omega_{\text {oabs }}$ wavelength dependence. Therefore, it should follow that $\omega_{\text {oabs }}$ can be used to infer the internal (or physicochemical) nature since each aerosol region exhibits a unique wavelength dependence reflecting either a pure aerosol type or a combination of aerosol types in the case of mixtures. Hence, this parameter along with the wavelength dependence in $\tau$ (or $\alpha_{440-870}$ ) can provide useful information for classifying aerosol types as described in Sect. 4.3.

\section{Results and discussions}

We employ the particle volume size distribution along with four aerosol parameters $-\tau_{440}, \tau_{\text {abs440 }}, \alpha_{440-870}$, and $\alpha_{\text {abs } 440-870}$ - in order to infer the regional and seasonal variation of aerosol types over the four selected AERONET sites. We analyze and discuss the annual and seasonal size distributions in Sect. 4.1 and monthly means of the aerosol parameters in Sect. 4.2. The annual and seasonal means as well as their standard deviations are summarized in Table 1. These two subsections will lay a foundation for a classification method involving the use of $\alpha_{440-870}$ and $\omega_{\text {oabs } 440}$ in Sect. 4.3.

\subsection{Annual and seasonal aerosol size distributions}

Figure 3 shows the annual and seasonal averaged particle volume size distributions from the four selected AERONET sites. As illustrated in Fig. 3a, both the Xianghe and Taihu sites show a bimodal distribution with a fine mode peak at $0.16 \mu \mathrm{m}$ and coarse mode peak near $3 \mu \mathrm{m}$. Note that Xianghe has a larger coarse than fine mode volume while the opposite is true for Taihu. The SACOL site is bimodal with a large coarse mode peak at $2.1 \mu \mathrm{m}$. Mukdahan is a near mirror image of SACOL, having a large fine mode peak at $0.2 \mu \mathrm{m}$. Though Fig. 3a shows the annual mean variations of aerosol size distribution, the seasonal variations of particle volume size distribution illustrates any possible periodic dependence of aerosol generation.

Figure 3b-e suggest that the Xianghe, Taihu and SACOL sites had coarse mode dominance during the spring season, which was likely due to mineral dust influences from both the Gobi and Taklamakan Deserts (Eck et al., 2005, 2010; Huang et al., 2008a, b). During the summer season, there is a change in aerosol size dominance from coarse to fine mode. The wet monsoon begins during the early summer season, which in turn enables southerly winds to transport pollution and biomass aerosols as well as moisture from the lower latitudes of southern and eastern Asia northward (Gautam et al., 2012; Eck et al., 2005). The increased humidity creates an abundance of suspended water droplets capable of facilitating gas to particle processes, which can lead to more fine mode aerosols (Yao et al., 2002; Pathak et al., 2009; Jin et al., 2011; Li et al., 2007a; Eck et al., 2005). SACOL also has a slightly larger fine mode during the summer season than during the spring, which is likely due to local pollution and biomass burning aerosol generation (Xin et al., 2007; Huang et al., 2008b). Mukdahan appears to be influenced by biomass burning activity throughout the dry season from numerous wildfires and ongoing agricultural activities (Gautam et al., 2012). It should be noted that due to wet monsoon activity the Taihu and Mukdahan sites have only limited observations of aerosols, especially during the summer months (Eck et al., 2005; Gautam et al., 2012).

During the autumn months (SON), there is a smaller fine mode volume contribution than the summer season at the Xianghe, Taihu, and SACOL sites. This likely reflects decreased humidity as well as diminished aerosol loading (as given by lower $\tau_{440}$ ) (Eck et al., 2005). At Taihu, the fine mode volume contribution is the highest of all four sites due to influences from local urban/industrial pollution (Shanghai) and biomass burning aerosols (Eck et al., 2010; Kondo et al., 2011; Xin et al., 2007). At the Mukdahan site, the fine mode $r_{\text {eff }}$ shifts from 0.16 to $0.25 \mu \mathrm{m}$ due to crop burning and other agricultural processes during this season (Gautam et al., 2012).

The winter months (DJF) show equal coarse and fine mode aerosol contributions at Taihu, while at the Xianghe site the coarse and fine modes are similar in magnitude as in the autumn months. Late winter dust activity (mineral dust and loose soil from bare farmlands) may also be responsible for the increased coarse mode influence at both Xianghe and SACOL (Huang et al., 2008b). Though the volume size distribution is useful in discerning aerosol influences according to size, the other aerosol parameters discussed in the following section will further illustrate aerosol influences according to type and composition.

\subsection{Seasonal variations of aerosol properties}

In Fig. 4a, Xianghe and Taihu both have summer maxima and late autumn/winter minima in $\tau_{440}$, with more variability at Xianghe indicating more aerosol sources (Pan et al., 2010; Xin et al., 2007; Yang et al., 2008, 2009). The increased variability seen at Taihu in the summer/early autumn is due to biomass aerosol intrusions (Xin et al., 2007). SACOL has maxima in April and June where the spring maximum can be attributed to strong dust activity beginning in early spring lasting to May, while the summer maximum (and maximum variability) corresponds to industrial influences from Lanzhou and biomass burning aerosols from 

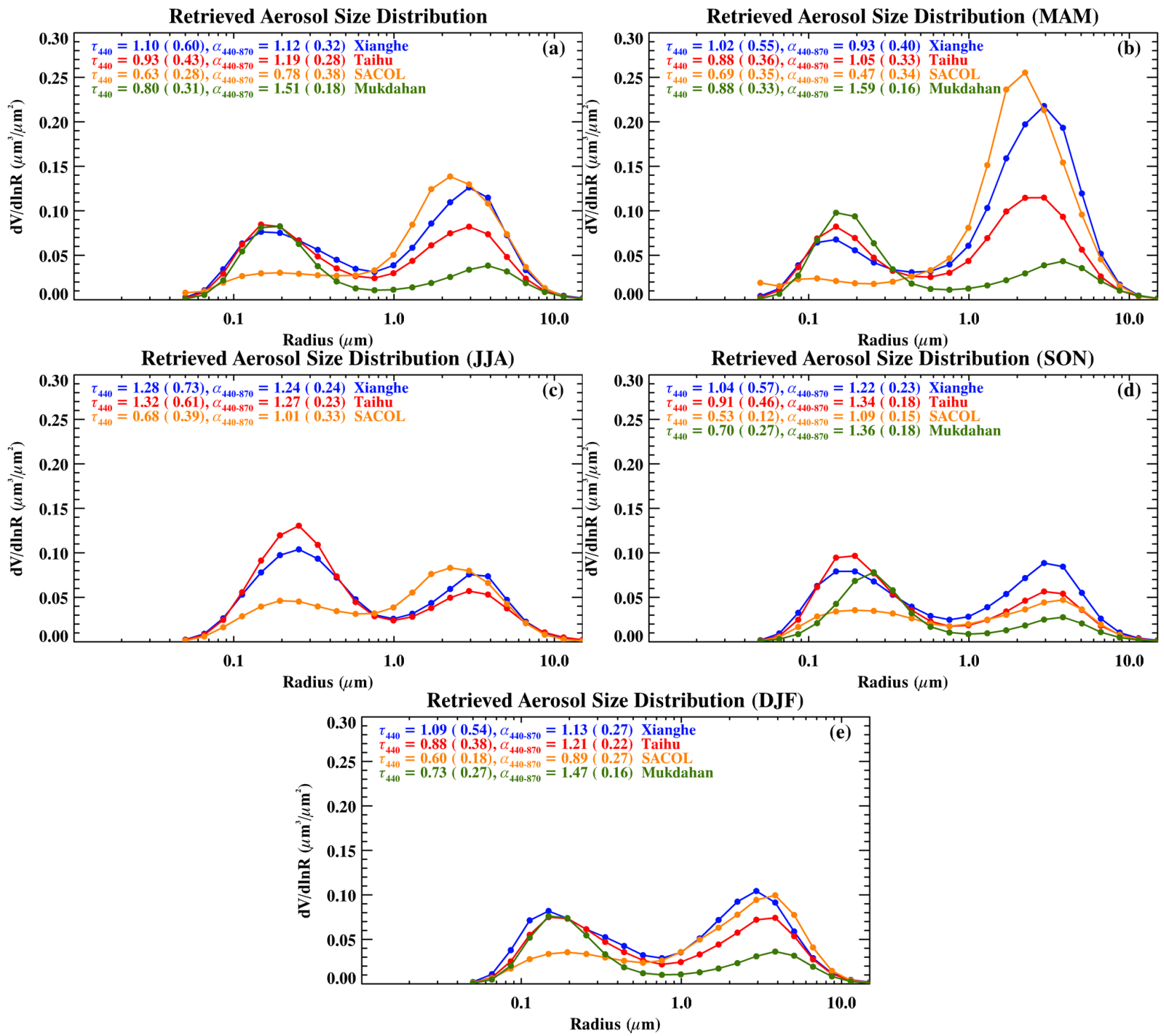

Fig. 3. Aerosol size distributions over the four selected AERONET sites. (a) Annual and (b-e) seasonal means (standard deviation) of aerosol optical depth $(\tau)$ and Ångström exponent $(\alpha)$ were calculated using data during the periods 2001-2010 (Xianghe), 2005-2010 (Taihu), 20062011 (SACOL), and 2003-2009 (Mukdahan). Note that there is no summer result at Mukdahan due to limited observations of aerosols.

neighboring regions (Xin et al., 2007; Huang et al., 2008b). At Mukdahan, biomass burning activity is at a maximum during March, with a second maximum in the autumn months after the rainy season (Gautam et al., 2012).

From Fig. 4b, Xianghe had both the largest $\tau_{\text {abs440 }}$ variability (0.045-0.14) and maximum $\tau_{\text {abs } 440}$ value (0.14). The summer minima and winter maxima at Xianghe and Taihu indicate that the different particles over these two sites were weakly absorbing during the summer months and strongly absorbing during the winter months. SACOL has near constant $\tau_{\text {abs440 }}$ values with a first maximum in the spring and lesser second maximum in the autumn, suggesting mineral dust episodes. Mukdahan had higher $\tau_{\mathrm{abs} 440}$ values during the pre-monsoon months that shifted to lower values after the rainy season.

Figure 4c illustrates the seasonal variation in $\alpha_{440-870}$ where Xianghe, Taihu, and SACOL had spring minima due to coarse mode, showing mineral dust particle influence with a more prolonged dust influence period at SACOL. The increase in $\alpha_{440-870}$ during the summer months is due to fine mode pollution and moisture influences at Xianghe and Taihu, while at SACOL ambient mineral dust mixes with local pollution from Lanzhou City. This is given by the increase in the volume fine mode while with volume coarse mode remains dominant (Fig. 2c), thereby keeping the mean $\alpha_{440-870}$ lower than the other sites (Clarke et al., 2004; Zheng et al., 2005; Xin et al., 2007). The monthly mean $\alpha_{440-870}$ values 

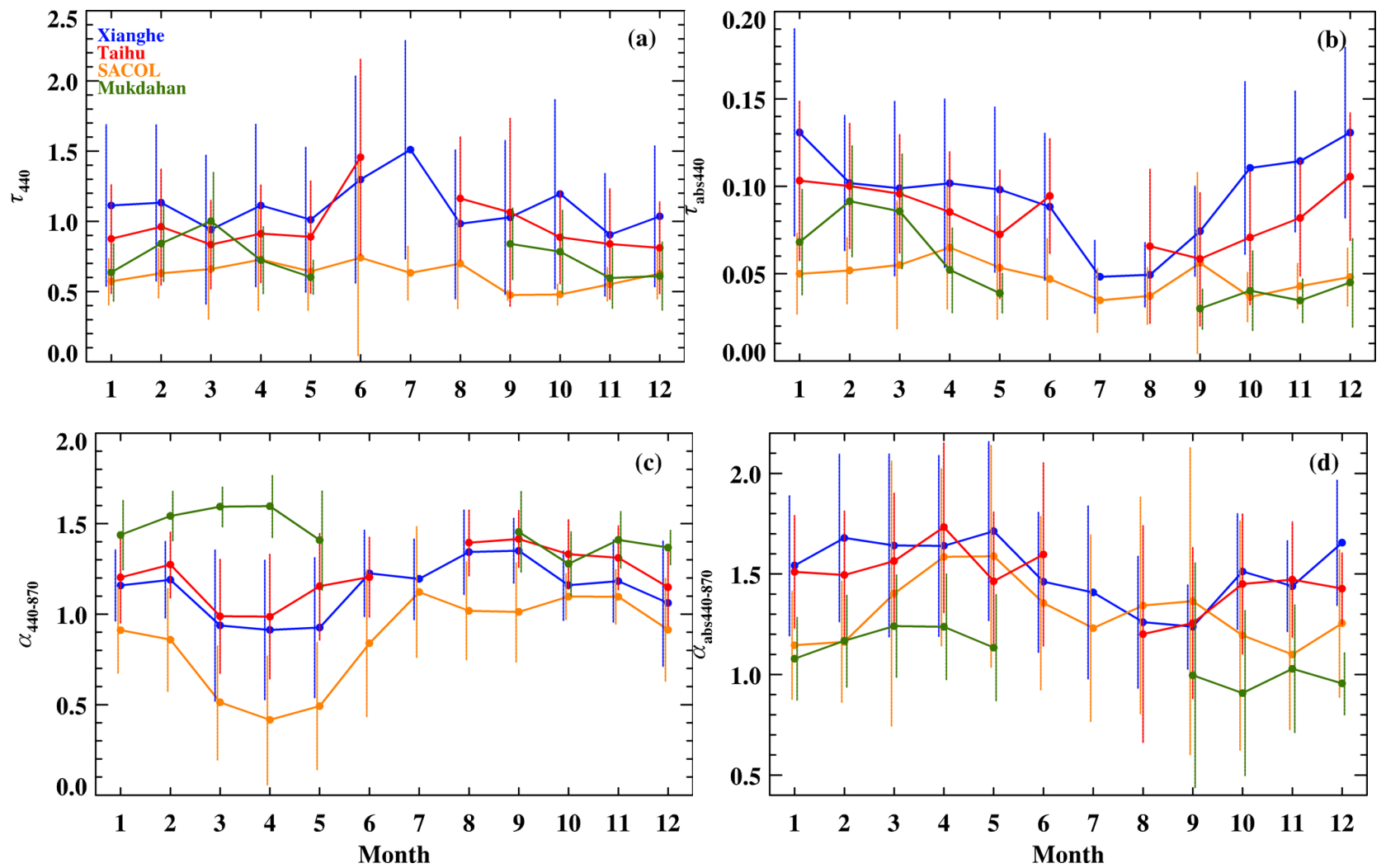

Fig. 4. Monthly means of the four parameters used in this study. Note that the missing monthly means at Taihu and Mukdahan are due to limited observations of aerosols during prolonged wet periods (summer season). The error bars represent $1 \omega$.

at Mukdahan are higher than those at the other three sites due to biomass burning particles being the dominant aerosol type (Gautam et al., 2012).

Figure $4 \mathrm{~d}$ shows the seasonal variation in $\alpha_{\mathrm{abs} 440-870}$. Both Xianghe and Taihu had similar $\alpha_{\mathrm{abs} 440-870}$ trends throughout the year except for late spring. The $\alpha_{\mathrm{abs}} 440-870$ values reach a maximum nearly a month earlier at Taihu because the dust storm season typically diminishes by early May, making it unlikely for mineral dust particles to greatly influence aerosol profiles in areas farther downwind of the Gobi and Taklamakan Deserts. It is more likely the maximum at Taihu in April is due to aerosols that are dominated by OC from industrial sources (Xin et al., 2007). During the summer, lower $\alpha_{\mathrm{abs} 440-870}$ values are exhibited at Xianghe and Taihu due to influences from sulfates and other carbonaceous aerosols with weak wavelength dependences (Yang et al., 2009; Russell et al., 2010). In the winter season, Xianghe has slightly higher $\alpha_{\text {abs } 440-870}$ values than Taihu due to carbonaceous aerosols generated from a combination of residential coal burning and industry (Yang et al., 2009; Zheng et al., 2005).

At SACOL, the monthly mean $\alpha_{\text {abs440-870 values typically }}$ reflect local urban and industrial pollution from Lanzhou City but increase significantly from the winter to the spring, and reach a maximum in April-May due to the strong dust activity in this region of Asia (Yang et al., 2009; Xin et al., 2007; Huang et al., 2008a, b). At Mukdahan, the monthly mean $\alpha_{\mathrm{abs} 440-870}$ values are lower than those from the other three sites, suggesting that the biomass particles exhibit a lesser wavelength dependence due to carbonaceous aerosols with more BC content than the other sites (Gautam et al., 2012; Yang et al., 2009).

The volume size distribution and the other parameters are useful in identifying regional and seasonal aerosol influences and characteristics. We explore the $\alpha_{440-870}$ and $\omega_{\text {oabs } 440}$ parameters as a means of further supporting our results by using aerosol cases from regions dominated by pollution (absorbing and scattering dominant), mineral dust, and biomass particles. We then show how the four Asian sites are approximate combinations of the selected regions.

\subsection{A classification method involving $\alpha_{440-870}$ and $\omega_{\text {oabs } 440}$}

As demonstrated in Sect. 3, the wavelength dependence of $\omega_{\text {oabs }}$ provides more information than $\tau_{\mathrm{abs}}$ as to the physicochemical properties of the aerosol types discussed in this study in addition to the $\alpha_{440-870}$ parameter representing particle size. Thus, we combine these two parameters to illustrate a simple classification method. Since the four selected 

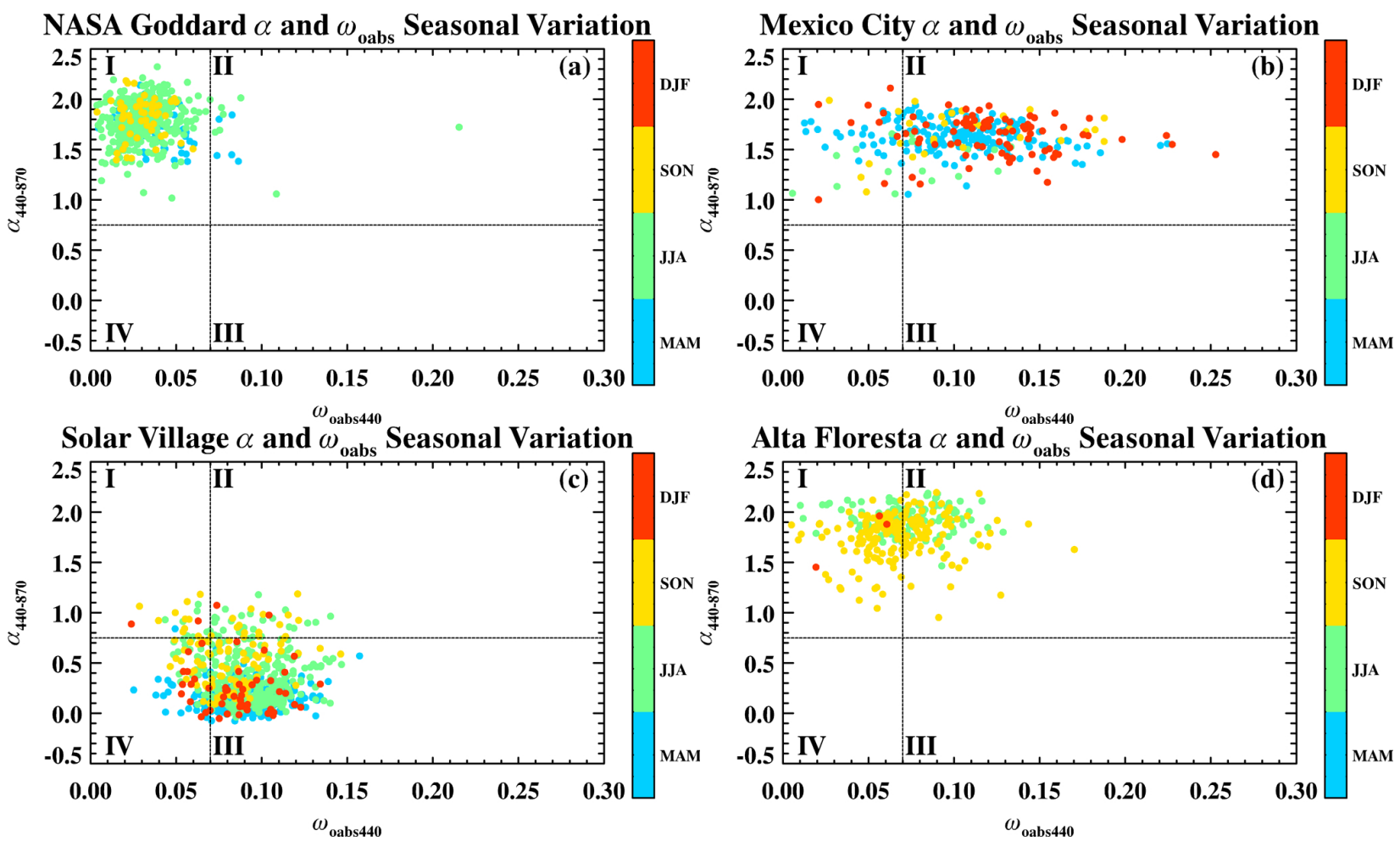

Fig. 5. Classification of four additional AERONET sites representing weakly absorbing (NASA Goddard) and strongly absorbing (Mexico City) pollution, mineral dust (Solar Village), and biomass burning (Alta Floresta) aerosol types. The time period for each site is 1993-2011 (NASA Goddard), 1999-2009 (Mexico City), 1999-2010 (Solar Village) and 1993-2010 (Mexico City). A threshold of $\alpha_{440-870}=0.75$ is used to define the fine $(>0.75)$ and coarse $(<0.75)$ mode aerosols, while weakly $\left(\omega_{\text {oabs } 440}<0.07\right)$ and strongly $\left(\omega_{\text {oabs } 440}>0.07\right)$ absorbing aerosols are set at $\omega_{\text {oabs } 440}=0.07$. Solar Village is near Riyadh, Saudi Arabia, which is dominated primarily by mineral dust aerosols but can be occasionally influenced by urban aerosols. It should be noted that winter, spring, and summer cases are presented at the Alta Floresta site (Southern Hemisphere).

Asian sites are more or less influenced by several aerosol types, as discussed in the previous section, we have analyzed four additional AERONET sites that are dominated by a single aerosol type. We first apply our method to these four additional AERONET sites to demonstrate how it works. This will aid in serving as a baseline for analyzing the aerosol properties over the four selected Asian sites.

Figure 5 presents the results of four additional AERONET sites that reflect source regions dominated by weakly absorbing pollution [NASA Goddard $\left(38.99^{\circ} \mathrm{N}, 76.84^{\circ} \mathrm{W}\right)$ ], strongly absorbing pollution [Mexico City $\left(19.34^{\circ} \mathrm{N}\right.$, $\left.99.18^{\circ} \mathrm{W}\right)$ ], strongly absorbing mineral dust [Solar Village $\left(24.91^{\circ} \mathrm{N}, 46.40^{\circ} \mathrm{E}\right)$ ], and biomass burning particles [Alta Floresta $\left(9.87^{\circ} \mathrm{S}, 56.10^{\circ} \mathrm{W}\right)$ ] (Dubovik et al., 2002; Chung et al., 2012). We performed a frequency analysis of all aerosol cases from the four single mode dominant aerosol sites and determined a $\omega_{\text {oabs } 440}$ value of 0.07 as a demarcation line between strongly and weakly absorbing aerosols (results not shown). For the two pollution sites their aerosol particles are dominated by fine mode $\left(\alpha_{440-870}>0.75\right)$, therefore we define Region I as weakly absorbing particle dominance (most of $\omega_{\text {oabs }}$ values $<0.07$ ) and Region II as strongly absorbing particle dominance (most of $\omega_{\text {oabs } 440}$ values $>0.07$ ). Note that Mexico City has large $\omega_{\text {oabs }}$ variability with the majority of the aerosol cases located at Region II. Region III represents coarse mode, strongly absorbing mineral dust aerosol cases $\left(\alpha_{440-870}<0.75\right)$. Region IV represents coarse mode, weakly absorbing aerosols that are primarily observed at the Solar Village site (desert).

Figure $6 \mathrm{a}$ and $\mathrm{b}$ detail three seasonal groups of aerosols at Xianghe and Taihu. There is a noticeable seasonal dependence at Xianghe, with nearly $55 \%$ of the fine mode, weakly absorbing cases occurring during the summer (Region I) and $90 \%$ of all fine mode, strongly absorbing cases occurring in the autumn and winter seasons (Region II). The coarse mode, strongly absorbing aerosols are observed during the spring season primarily in Region III. Similarly at Taihu, $48 \%$ of the fine mode, weakly absorbing cases in Region I occur during the early autumn, while $75 \%$ of the fine mode, strongly absorbing cases occur during the late autumn and winter (Region II). Nearly $22 \%$ of the spring season aerosols are coarse mode, strongly absorbing.

At SACOL, all four regions contain aerosol cases with the majority of the spring season cases located in Regions 

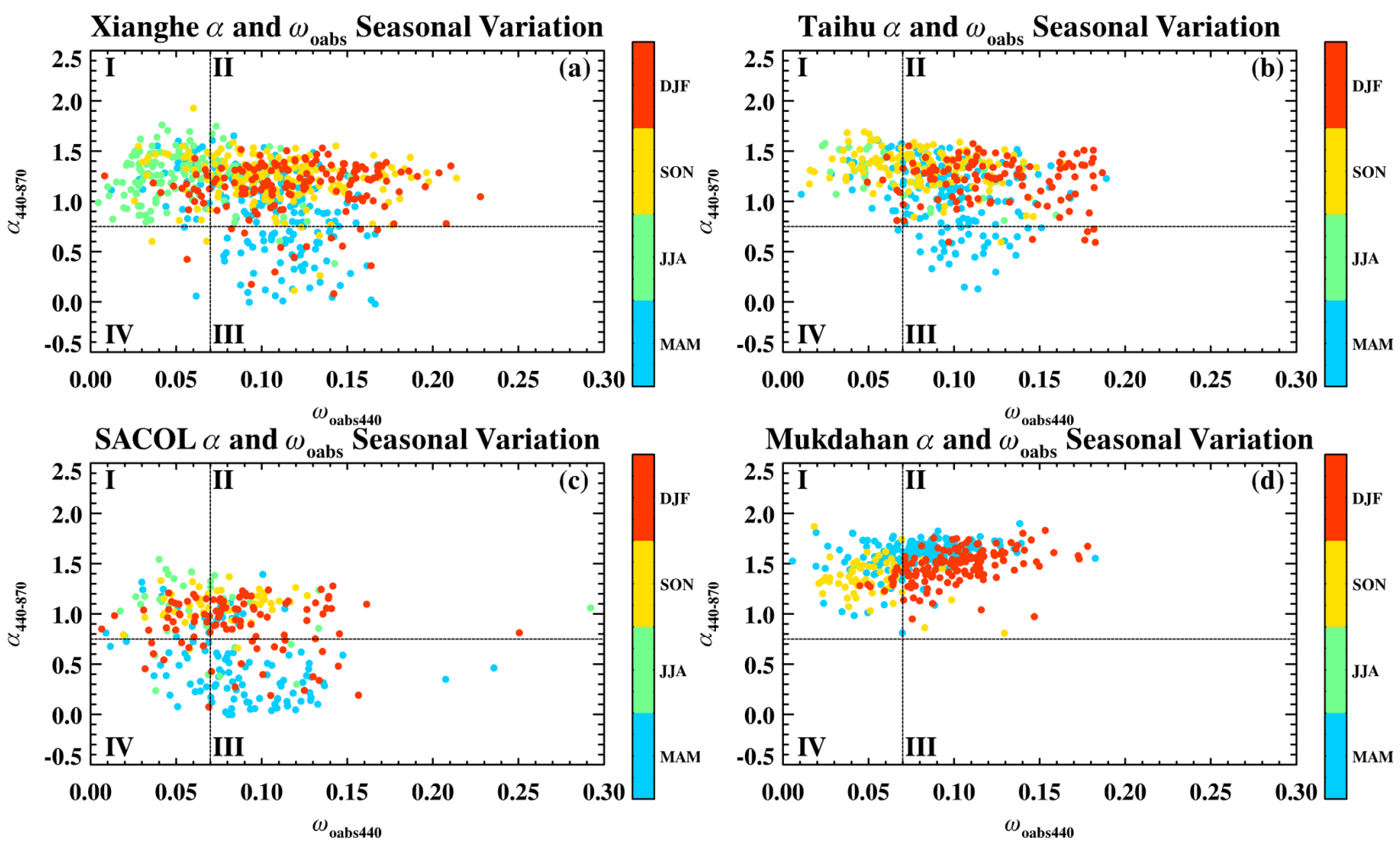

Fig. 6. Classification of the aerosol physico-chemical properties over the four selected AERONET sites. The data are color-coded according to season to show correlations between aerosol composition/type and time of year.

III and IV (similar to the Solar Village site). The majority of the winter and autumn season aerosols are in Region II while the summer cases are in Region I. The mean $\alpha_{440-870}$ and $\omega_{\text {oabs } 440}$ values are lower in comparison to Xianghe and Taihu. This is due to the fact that SACOL is located within a dust region with fewer cities and outside aerosol influences, while Xianghe and Taihu are surrounded by many large cities and industry (Eck et al., 2005; Xin et al., 2007; Bi et al., 2009; Yang et al., 2009). This is also evident in Fig. $4 \mathrm{c}$ and d where both the $\alpha_{440-870}$ and $\alpha_{\mathrm{abs} 440-870}$ values for this site were lower than those at Xianghe and Taihu.

Comparing the Region I and II results at Mukdahan with Xianghe and Taihu, we note the higher overall $\alpha_{440-870}$ values for the biomass burning aerosols present (Fig. 6d). The variability in $\omega_{\text {oabs } 440}$ is likely due to a wide variety of OC and $\mathrm{BC}$ particles generated by different smoldering or flaming combustion modes (Yang et al., 2009; Zheng et al., 2005; Reid et al., 1999; Gautam et al., 2012; Clarke et al., 2004). There is also a noticeable seasonal dependence where $90 \%$ of the winter cases are located at Region II while most of the autumn cases $(88 \%)$ are generally in Region I. The spring season has the largest variability in $\omega_{\text {oabs } 440}$, presumably due to aerosol influences from both controlled agricultural burning and natural wildfires from nearby forests (Gautam et al., 2012).
The large variability in $\alpha_{440-870}$ and $\omega_{\text {oabs } 440}$ classified in this method can be challenging. A great deal of overlap is evident, which is likely attributed to inter-seasonal shifts in aerosol type due to episodic changes in fuel type and meteorological patterns (Eck et al., 2005; Clarke et al., 2004). The overlap can also be attributed to inhomogeneous aerosol layers passing over the AERONET sites that add to the variability. At other AERONET sites affected by multiple aerosol sources (e.g. Africa and India), an a priori knowledge of the regional and seasonal climatology will aid in using this method.

\section{Summary and conclusions}

In this study, four Asian AERONET sites have been selected to represent aerosol properties reflecting biomass burning (Mukdahan), desert-urban (SACOL), pollution (Taihu), and complex mixed particle type (Xianghe) influences. Each site exhibits a wavelength dependence in $\tau, \tau_{\mathrm{abs}}$, and $\omega_{\text {oabs }}$ that is indicative of the mean aerosol extinctive and absorptive behavior of the region. However, the absorptive parameters, $\tau_{\text {abs }}$ and $\omega_{\text {oabs }}$, suggest multiple influences of carbonaceous (BC and $\mathrm{OC}$ ) and mineral dust aerosols, especially at Xianghe and SACOL. Therefore, the volume particle size distribution and five robust parameters $\left(\tau_{440}, \tau_{\mathrm{abs} 440}\right.$, $\alpha_{440-870}, \alpha_{\mathrm{abs} 440-870}$, and $\left.\omega_{\text {oabs }}\right)$ have been investigated to 
reveal a seasonal dependence of aerosol type and composition at these sites. Mineral dust influences are clearly seen at Xianghe, Taihu, and SACOL, primarily during the spring months (MAM) as illustrated by the large coarse mode particle volume distribution, low $\alpha_{440-870}$, and ele-

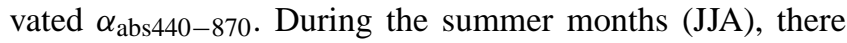
is a shift towards fine mode, weakly absorbing aerosols derived primarily from anthropogenic sources as given by an increase in the fine mode particle volume distribution, high $\alpha_{440-870}$, and low $\alpha_{\text {abs } 440-870}$ values at Xianghe, Taihu, and SACOL. The autumn months (SON) show influences from biomass burning, then a shift towards more absorbing aerosols at Xianghe and Taihu. During the winter (DJF), BC and OC particles are dominant at Xianghe, Taihu and SACOL as given by high $\alpha_{440-870}$ and elevated $\alpha_{\mathrm{abs} 440-870}$. Mukdahan has the largest overall fine mode particle dominance, highest $\alpha_{440-870}$, and lowest $\alpha_{\mathrm{abs} 440-870}$ values, indicating biomass burning particles that reflect contributions from weakly and strongly absorbing carbonaceous influences. We develop a classification method based upon the $\alpha_{440-870}$ and $\omega_{\text {oabs } 440}$ parameters in order to illustrate distinct groups of seasonal aerosol cases comprised of pollution, mineral dust, and biomass particles. This method involves isolating the aerosol physico-chemical properties into four separate regions according to their size and absorptive properties while color coding them by season. We first apply this method to four additional AERONET sites (NASA Goddard, Mexico City, Solar Village, and Alta Floresta) representing dominant single mode aerosol regions in order to illustrate the relative contributions and seasonal dependence of aerosol types at the four selected sites used in this study. Both Xianghe and Taihu have three identifiable seasonal variations of aerosol types reflecting the influences of local urban/industrial emissions, biomass burning aerosols, mineral dust (Regions I-III). SACOL has aerosol cases that occupy all four regions, with the majority of the spring cases in Region III (mineral dust) and the winter/autumn cases in Region II (urban/industrial pollution). The weakly absorbing aerosols in Regions I and IV are likely due to outside aerosol influences that mix with local mineral dust (lower overall $\alpha_{440-870)}$. The aerosol cases at Mukdahan occupy Regions I and II, similar to Xianghe and Taihu, but have the highest overall $\alpha_{440-870}$ values (fine mode) and are shown to have a seasonal dependence in aerosol absorptive properties with strongly absorbing biomass burning aerosols in the winter and weakly absorbing biomass aerosols in the autumn.

The results of this study will provide a ground truth to validate satellite-retrieved and model-simulated aerosol single scattering properties. For example, MODIS aerosol retrievals assume these properties by region without taking into account the seasonal and regional variability shown by the classification method. This study also illustrates the broad fingerprint of regions that are seasonally influenced by different types of aerosols.
Acknowledgements. The authors are grateful for the NASA Goddard, Mukdahan, and Alta Floresta AERONET data provided by P.I. Brent Holben and his staff. We also thank P.I.s Jianping Huang and Wu Zhang for the SACOL AERONET data, P.I. Amando Leyva Contreras for the Mexico City AERONET data, and P.I. Naif Al-Abbadi for the Solar Village AERONET data. Figure 1 is provided by NASA World Wind software provided at http://worldwind.arc.nasa.gov/index.html. Additional thanks goes to Terry Nakajima, Soonchang Yoon, Sang-Woo Kim, Jianglong Zhang, Zhe Feng, Aaron Kennedy, and graduate students for their insightful and helpful comments for this manuscript. This research was supported by the Ministry of Science and Technology of China with award number 2013CB955800 at Beijing Normal University. Researchers at University of North Dakota were supported by NASA EPSCoR CAN under grant NNX11AM15A at University of North Dakota.

Edited by: T. Wang

\section{References}

Andreae, M. O. and Gelencsér, A.: Black carbon or brown carbon? The nature of light-absorbing carbonaceous aerosols, Atmos. Chem. Phys., 6, 3131-3148, doi:10.5194/acp-6-3131-2006, 2006.

Bergstrom, R. W., Russell, P. B., and Hingett, P.: Wavelength Dependence of the Absorption of Black Carbon Particles: Predictions and Results from the TARFOX Experiment and Implications for the Aerosol Single Scattering Albedo, J. Atmos. Sci., 59, 567-577, 2002.

Bergstrom, R. W., Pilewskie, P., Pommier, J., Rabbette, M., Russell, P. B., Schmid, B., Redemann, J., Higurashi, A., Nakajima, T., and Quinn, P. K.: Spectral absorption of solar radiation by aerosols during ACE-Asia, J. Geophys. Res., 109, D19S15, doi:10.1029/2003JD004467, 2004.

Bergstrom, R. W., Pilewskie, P., Russell, P. B., Redemann, J., Bond, T. C., Quinn, P. K., and Sierau, B.: Spectral absorption properties of atmospheric aerosols, Atmos. Chem. Phys., 7, 5937-5943, doi:10.5194/acp-7-5937-2007, 2007.

Bi, J., Huang, J., Fu, Q., Wang, X., Shi, J., Zhang, W., Huang, Z., and Zhang, B.: Toward characterization of the aerosol optical properties over Loess Plateau of Northwestern China, J. Quant. Spectrosc. Ra., 112, 346-360, doi:10.1016/j.jqsrt.2010.09.006, 2010.

Clarke, A. D., Shinozuka, Y., Kapustin, V. N., Howell, S., Huebert, B., Doherty, S., Anderson, T., Covert, D., Anderson, J., Hua X., Moore, K. G. II, McNaughton, C., Carmichael, G., and Weber, R.: Size distributions and mixtures of dust and black carbon aerosol in Asian outflow: Physiochemistry and optical properties, J. Geophys. Res., 109, D15S09, doi:10.1029/2003JD004378, 2004.

Corrigan, C. E., Ramanathan, V., and Schauer, J. J.: Impact of monsoon transitions on the physical and optical properties of aerosols, J. Geophys. Res., 111, D18208, doi:10.1029/2005JD006370, 2006.

Chung, C. E., Ramanathan, V., and Decremer, D.: Observationally constrained estimates of carbonaceous aerosol radiative forcing, P. Natl. Acad. Sci. USA, 109, 11624-11629, 2012. 
Dubovik, O. and King, M.: A flexible inversion algorithm for retrieval of aerosol optical properties from Sun and sky radiance measurements, J. Geophys. Res., 105, 20673-20696, 2000.

Dubovik, O., Smirnov, A., Holben, B. N., Eck, T. F., King, M. D., Kaufman, Y. J., and Slutsker, I.: Accuracy assessments of aerosol optical properties retrieved from Aerosol Robotic Network (AERONET) Sun and sky radiance measurements, J. Geophys. Res., 105, 9791-9806, 2000.

Dubovik, O., Holben, B., Eck, T. F., Smirnov, A., Kaufman, Y. J., King, M. D., Tanré, D., and Slutsker, I.: Variability of Absorption and Optical Properties of Key Aerosol Types Observed in Worldwide Locations, J. Atmos. Sci., 59, 590-608, 2002.

Eck, T. F., Holben, B. N., Reid, J. S., Dubovik, O., Smirnov, A., O'Neill, N. T., Slutsker, I., and Kinne, S.: Wavelength dependence of the optical depth of biomass burning, urban, and desert dust aerosols, J. Geophys. Res., D24, 31333-31349, 1999.

Eck, T. F., Holben, B. N., Dubovik, O., Smirnov, A., Goloub, P., Chen, H. B., Chatenet, B., Gomes, L., Zhang, X.-Y., Tsay, S.C., Ji, Q., Giles, D., and Slutsker, I.: Columnar aerosol optical properties at AERONET sites in central eastern Asia and aerosol transport to the tropical mid-Pacific, J. Geophys. Res., 110, D06202, doi:10.1029/2004JD005274, 2005.

Eck, T. F., Holben, B. N., Sinyuk, A., Pinker, R. T., Goloub, P., Chen, H., Chatenet, B., Li, Z., Singh, R. P., Tripathi, S. N., Reid, J. S., Giles, D. M., Dubovik, O., O’Neill, N. T., Smirnov, A., Wang, P., and Xia, X.: Climatological aspects of the optical properties of fine/coarse mode aerosol mixtures, J. Geophys. Res., 115, D19205, doi:10.1029/2010JD014002, 2010.

Gautam, R., Hsu, N. C., Eck, T. F., Holben, B. N., Janjai, S., Jantarach, T., Tsay, S.-C., and Lau, W. K.: Characterization of aerosols over the Indochina peninsula from satellite-surface observations during biomass burning pre-monsoon season, Atmos. Environ., doi:10.1016/j.atmosenv.2012.05.038, in press, 2012.

Giles, D. M., Holben, B. N., Tripathi, S. N., Eck, T. F., Newcomb, W. W., Slutsker, I., Dickerson, R. R., Thompson, A. M., Mattoo, S., Wang, S.-H., Singh, R. P., Sinyuk, A., and Schafer, J. S.: Aerosol properties over the Indo-Gangetic Plain: A mesoscale perspective from the TIGERZ experiment, J. Geophys. Res., 116, D18203, doi:10.1029/2011JD015809, 2011.

Gobbi, G. P., Kaufman, Y. J., Koren, I., and Eck, T. F.: Classification of aerosol properties derived from AERONET direct sun data, Atmos. Chem. Phys., 7, 453-458, doi:10.5194/acp-7-453-2007, 2007.

Gyawali, M., Arnott, W. P., Lewis, K., and Moosmüller, H.: In situ aerosol optics in Reno, NV, USA during and after the summer 2008 California wildfires and the influence of absorbing and non-absorbing organic coatings on spectral light absorption, Atmos. Chem. Phys., 9, 8007-8015, doi:10.5194/acp-9-8007-2009, 2009.

Hansen, J. and Sato, M.: Trends of measured climate forcing agents, P. Natl. Acad. Sci., 98, 14778-14783, 2001.

Higurashi, A. and Nakajima, T.: Detection of aerosol types over the East China Sea near Japan from four-channel satellite data, Geophys. Res. Lett., 29, 1836, doi:10.1029/2002GL015357, 2002.

Huang, J., Minnis, P., Chen, B., Huang, Z., Liu, Z., Zhao, Q., Yi, Y., and Ayers, J. K.: Long-range transport and vertical structure of Asian dust from CALIPSO and surface measurements during PACDEX, J. Geophys. Res., 113, D23212, doi:10.1029/2008JD010620, 2008a.
Huang, J. P., Zhang, W., Zuo, J. Q., Bi, J. R., Shi, J. S., Wang, X., Chang, Z. L., Huang, Z. W., Yang, S., Zhang, B. D., Wang, G. Y., Feng, G. H., Yuan, J. Y., Zhang, L., Zuo, H. C., Wang, S. G., Fu, C. B., and Chou, J. F.: An overview of the semi-arid climate and environment research observatory over the Loess Plateau, Adv. Atmos. Sci., 25, 906-921, doi:10.1007/s00376-008-09067, 2008b.

Holben, B. N., Eck, T. F., Slutsker, I., Tanré, D., Buis, J. P., Setzer, A., Vermote, E., Reagan, J. A., Kaufman, Y. J., Nakajima, T., Lavenu, F., Jankowiak, I., and Smirnov, A.: AERONET - A federated instrument network and data archive for aerosol characterization, Remote Sens. Environ., 66, 1-16, 1998.

Holben, B. N., Eck, T. F., Slutsker, I., Smirnov, Sinyuk, A., Schafer, A. J., Giles, D., and Dubovik, O.: AERONET's version 2.0 quality assurance criteria, Remote Sensing of Atmosphere and Clouds, Proc. SPIE Int. Soc. Opt. Eng., 6408, 64080Q, doi:10.1117/12.706524, 2006.

Intergovernmental Panel on Climate Change (IPCC): Climate Change 2007: The Physical Science Basis. Contribution of Working Group I to the Fourth Assessment Report of the Intergovernmental Panel on Climate Change, edited by: Solomon, S., Qin, D., Manning, M., Chen, Z., Marquis, M., Averyt, K. B., Tignor, M., and Miller, H. L., Cambridge Univ. Press, New York, 2007.

Jeong, M.-J. and Li, Z.: Quality, compatibility, and synergy analyses of global aerosol products derived from the advanced very high resolution radiometer and Total Ozone Mapping Spectrometer, J. Geophys. Res., 110, D10S08, doi:10.1029/2004JD004647, 2005.

Jin, M. S., Kessomkiat, W., and Pereira, G.: Satellite-Observed Urbanization Characters in Shanghai, China: Aerosols, Urban Heat Island Effect, and Land-Atmosphere Interactions, Remote Sens., 3, 83-99, doi:10.3390/rs3010083, 2011.

Kaufman, Y. J., Tanré D., and Boucher O.: A satellite view of aerosols in the climate system, Nature, 419, 215-223, doi:10.1038/nature01091, 2002.

Kondo, Y., Matsui, H., Moteki, N., Sahu, L., Takegawa, N., Kajino, M., Zhao, Y., Cubison, M. J., Jimenez, J. L., Vay, S., Diskin, G. S., Anderson, B., Wisthaler, A., Mikoviny, T., Fuelberg, H. E., Blake, D. R., Huey, G., Weinheimer, A. J., Knapp, D. J., and Brune, W. H.: Emissions of black carbon, organic, and inorganic aerosols from biomass burning in North America and Asia in 2008, J. Geophys. Res., 116, D08204, doi:10.1029/2010JD015152, 2011.

Koven, C. D. and Fung, I.: Inferring dust composition from wavelength-dependent absorption in Aerosol Robotic Network (AERONET) data, J. Geophys. Res., 111, D14205, doi:10.1029/2005JD006678, 2006.

Lack, D. A. and Cappa, C. D.: Impact of brown and clear carbon on light absorption enhancement, single scatter albedo and absorption wavelength dependence of black carbon, Atmos. Chem. Phys., 10, 4207-4220, doi:10.5194/acp-10-4207-2010, 2010.

Levin, Z., Ganor, E., and Gladstein, V.: The effects of desert particles coated with sulfate on rain formation in the eastern Mediterranean, J. Appl. Meteorol., 35, 1511-1523, 1996.

Lewis, K., Arnott, W. P., Moosmüller, H., and Wold, C. E.: Strong spectral variation of biomass smoke light absorption and single scattering albedo observed with a novel dual-wavelength photoacoustic instrument, J. Geophys. Res., 113, D16203, doi:10.1029/2007JD009699, 2008. 
Li, Z., Chen, H., Cribb, M., Dickerson, R., Holben, B., Li, C., Lu, D., Luo, Y., Maring, H., Shi, G., Tsay, S.-C., Wang, P., Wang, Y., Xia, X., Zheng, Y., Yuan, T., and Zhao, F.: Aerosol optical properties and its radiative effects in northern China, J. Geophys. Res., 112, D22S01, doi:10.1029/2006JD007382, 2007a.

Li, Z., Chen, H., Cribb, M., Dickerson, R., Holben, B., Li, C., Lu, D., Luo, Y., Maring, H., and Shi, G.: Preface to special section on East Asian Studies of Tropospheric Aerosols: An International Regional Experiment (EAST-AIRE), J. Geophys. Res., 112, D22S00, doi:10.1029/2007JD008853, 2007b.

Logan, T., Xi, B., Dong, X., Obrecht, R., Li, Z., and Cribb, M.: A study of Asian dust plumes using satellite, surface, and aircraft measurements during the INTEX-B field experiment, J. Geophys. Res., 115, D00K25, doi:10.1029/2010JD014134, 2010.

McNaughton, C. S., Clarke, A. D., Kapustin, V., Shinozuka, Y., Howell, S. G., Anderson, B. E., Winstead, E., Dibb, J., Scheuer, E., Cohen, R. C., Wooldridge, P., Perring, A., Huey, L. G., Kim, S., Jimenez, J. L., Dunlea, E. J., DeCarlo, P. F., Wennberg, P. O., Crounse, J. D., Weinheimer, A. J., and Flocke, F.: Observations of heterogeneous reactions between Asian pollution and mineral dust over the Eastern North Pacific during INTEX-B, Atmos. Chem. Phys., 9, 8283-8308, doi:10.5194/acp-9-8283-2009, 2009.

Pan, L., Che, H., Geng, F., Xia, X., Wang, Y., Zhu, C., Chen, M., Gao, W., and Guo, J.: Aerosol optical properties based on ground measurements over the Chinese Yangtze Delta Region, Atmos. Environ., 44, 2587-2596, 2010.

Pathak, R. K., Wu, W. S., and Wang, T.: Summertime $\mathrm{PM}_{2.5}$ ionic species in four major cities of China: nitrate formation in an ammonia-deficient atmosphere, Atmos. Chem. Phys., 9, 17111722, doi:10.5194/acp-9-1711-2009, 2009.

Ramanathan, V., Crutzen, P. J., Kiehl, J. T., and Rosenfeld, D.: Aerosols, Climate, and the Hydrological Cycle, Science, 294, 2119-2124, doi:10.1126/science.1064034, 2001.

Reid, J. S., Eck, T. F., Christopher, S. A., Hobbs P. V., and Holben, B.: Use of the Angström exponent to estimate the variability of optical and physical properties of aging smoke particles in Brazil, J. Geophys. Res., 104, 27473-27489, 1999.

Russell, P. B., Bergstrom, R. W., Shinozuka, Y., Clarke, A. D., DeCarlo, P. F., Jimenez, J. L., Livingston, J. M., Redemann, J., Dubovik, O., and Strawa, A.: Absorption Angstrom Exponent in AERONET and related data as an indicator of aerosol composition, Atmos. Chem. Phys., 10, 1155-1169, doi:10.5194/acp-101155-2010, 2010.
Schuster, G. L., Dubovik, O., Holben, B. N., and Clothiaux, E. E.: Inferring black carbon content and specific absorption from Aerosol Robotic Network (AERONET) aerosol retrievals, J. Geophys. Res., 110, D10S17, doi:10.1029/2004JD004548, 2005.

Schuster, G. L., Dubovik, O., and Holben, B. N.: Angstrom exponent and bimodal aerosol size distributions, J. Geophys. Res., 111, D07207, doi:10.1029/2005JD006328, 2006.

Streets, D. G., Fu, J. S., Jang, C. J., Hao, J., Kebin, H., Tang, X., Zhang, Y., Wang, Z., Li, Z., Zhang, Q., Wang, L., Wang, B., and Yu, C.: Air quality during the 2008 Beijing Olympic Games, Atmos. Environ., 41, 480-492, 2007.

Xin, J., Wang, Y., Li, Z., Wang, P., Hao, W. M., Nordgren, B. L., Wang, S., Liu, G., Wang L., Wen T., Sun Y., and Hu, B.: Aerosol optical depth (AOD) and Ångström exponent of aerosols observed by the Chinese Sun Hazemeter Network from August 2004 to September 2005, J. Geophys. Res., 112, D05203, doi:10.1029/2006JD007075, 2007.

Yang, M., Howell, S. G., Zhuang, J., and Huebert, B. J.: Attribution of aerosol light absorption to black carbon, brown carbon, and dust in China - interpretations of atmospheric measurements during EAST-AIRE, Atmos. Chem. Phys., 9, 2035-2050, doi:10.5194/acp-9-2035-2009, 2009.

Yang, Y. Q., Hou, Q., Zhou, C. H., Liu, H. L., Wang, Y. Q., and Niu, T.: Sand/dust storm processes in Northeast Asia and associated large-scale circulations, Atmos. Chem. Phys., 8, 25-33, doi:10.5194/acp-8-25-2008, 2008.

Yao, X., Chan, C. K., Fang, M., Cadle, S., Chan, T., Mulawa, P., He, K., and Ye, B.: The water-soluble ionic composition of $\mathrm{PM}_{2.5}$ in Shanghai and Beijing, China, Atmos. Environ., 36, 4223-4234, 2002.

Zheng, M., Salmon, L. G., Schauer, J. J., Zeng, L., Kiang, C. S., Zhang, Y., and Cass, G. R.: Seasonal trends in $\mathrm{PM}_{2.5}$ source contributions in Beijing, China, Atmos. Environ., 39, 3967-3976, 2005. 